\title{
Hydrogen soil deposition at an urban site in Finland
}

\author{
M. Lallo, T. Aalto, J. Hatakka, and T. Laurila \\ Finnish Meteorological Institute, Helsinki, Finland \\ Received: 10 June 2009 - Published in Atmos. Chem. Phys. Discuss.: 9 July 2009 \\ Revised: 17 October 2009 - Accepted: 28 October 2009 - Published: 11 November 2009
}

\begin{abstract}
Hydrogen deposition velocities $\left(v_{d}\right)$ were estimated by field chamber measurements and model simulations. A closed-chamber method was used for soil deposition studies in Helsinki, Finland, at an urban park inhabited by broad-leaved trees. Radon tracer method was used to estimate the $v_{d}$ in nighttime when photochemical reactions were minimal and radon gas was concentrated in the shallow boundary layer due to exhalation from soil. A two-dimensional atmospheric model was used for the calculation of respective $v_{d}$ values and radon exhalation rates. The $v_{d}$ and radon exhalation rates were lower in winter than in summer according to all methods. The radon tracer method and the two-dimensional model results for hydrogen deposition velocity were in the range of $0.13 \mathrm{~mm} \mathrm{~s}^{-1}$ to $0.93 \mathrm{~mm} \mathrm{~s}^{-1}$ (radon tracer) and $0.12 \mathrm{~mm} \mathrm{~s}^{-1}$ to $0.61 \mathrm{~mm} \mathrm{~s}^{-1}$ (two-dimensional). The soil chamber results for $v_{d}$ were $0.00 \mathrm{~mm} \mathrm{~s}^{-1}$ to $0.70 \mathrm{~mm} \mathrm{~s}^{-1}$. Both models and chamber measurements revealed a relation between one week cumulative rain sum and deposition velocity. When precipitation events occurred a few days before the chamber measurements, lower $v_{d}$ values were observed. A snow cover also lowered $v_{d}$.
\end{abstract}

\section{Introduction}

There is a need to better understand interactions of molecular hydrogen in the atmosphere. The interest to develop carbon dioxide free energy production methods promotes the hydrogen economy goals to utilize hydrogen as an energy transport media. Energy produced using cleaner methods (e.g. wind power) can be used to split water to hydrogen (and oxygen) electrochemically. The interest in hydrogen in the past few

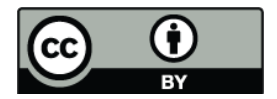

Correspondence to: M. Lallo

(marko.lallo@fmi.fi) years has accelerated and steered research to find out processes, where hydrogen is participating, these include stratospheric (Rahn et al., 2003; Röckmann et al. 2003) and tropospheric studies (Barnes et al., 2003). Several authors have reported that soil uptake is the largest sink, which is responsible for $73-82 \%$ of total hydrogen turnover (Novelli et al., 1999; Hauglustaine and Ehhalt, 2002; Rhee et al., 2006). The soil uptake is higher in Northern Hemisphere due to larger land coverage. An extensive review of tropospheric hydrogen cycle was made by Ehhalt and Rohrer (2009). A companion article by Aalto et al. (2009) is focused on atmospheric variations and to the traffic emission of hydrogen. Recent field measurements to estimate soil uptake of hydrogen were made in agricultural area in Heidelberg (Schmitt et al., 2009), in forest, marsh and desert area in California (Smith-Downey et al., 2008), in northern boreal zone (Lallo et al., 2008) in Alaska (Rahn et al., 2002). Yonemura et al. $(1999,2000)$ made field studies in a temperate forest and in an arable field in Japan. Earlier field measurements were made by Conrad and Seiler $(1980,1985)$ in Germany and in Africa. Soil microbes and free soil enzymes are responsible for hydrogen uptake (Conrad, 1996; Constant et al., 2008, 2009), and soil hydrogenases that are responsible for hydrogen uptake have recently been extracted by Guo and Conrad (2008) and Constant et al. (2008). Photochemical production and destruction of atmospheric hydrogen is hydroxyl radical controlled. (Schmidt, 1974; Sanders, 2006; Simmonds et al., 2000). Radon tracer method is suitable for estimating various greenhouse gas emissions (Zahorovski et al., 2006) including nitrous oxide (Schmidt et al., 2001), methane (Levin et al., 1999) and carbon dioxide (Langendörfer et al., 2002), and has recently been applied for hydrogen by Hammer and Levin (2009). The regional representativeness of radon tracer method depends on an integration time of fluxes, site topography and meteorological parameters (Levin et al., 1999). The results are dependent on radon exhalation rate, which depends mainly on

Published by Copernicus Publications on behalf of the European Geosciences Union. 
a grain size distribution and a soil porosity. A high soil moisture/water content is also known to hinder radon exhalation (Levin et al., 2002). The latitudinal distribution of ${ }^{222} \mathrm{Rn}$ flux is examined by Conen and Robertson (2002). A simple twodimensional atmospheric model, based on earlier work by Aalto et al. (2006) and Lallo et al. (2009), was utilized to estimate local radon exhalation and hydrogen uptake rates by inverting soil fluxes from atmospheric measurements. These two models and chamber measurements were used to evaluate the soil sink strength and were compared against each other. Ehhalt and Rohrer (2009) reported based on the findings of Price et al. (2007) and Novelli (1999). The hydrogen mixing ratio is asymmetrically distributed between the hemispheres. In Northern Hemisphere (NH) it reaches $490 \mathrm{ppb}$ at $80^{\circ} \mathrm{N}$. In Southern Hemisphere (SH) mixing ratio reaches $535 \mathrm{ppb}$ at $88^{\circ} \mathrm{S}$. Barnes et al. (2003) observed a seasonal cycle for mixing ratio of atmospheric hydrogen in Harvard forest with the maximum in winter and spring months (February to June) and a short minimum in September-October. Simmonds et al. (2000) observed a similar seasonal cycle with the highest mixing ratio during the spring months of March to May and the lowest values in September to November. Rhee et al. (2006) estimated a total budget for $\mathrm{NH}$, where the total hydrogen sources were $69 \mathrm{Tg}\left(\mathrm{H}_{2}\right) \mathrm{a}^{-1}$ and $62 \mathrm{Tg}\left(\mathrm{H}_{2}\right) \mathrm{a}^{-1}$ of the total sources were consumed by soils. For the $\mathrm{SH}$ total hydrogen sources was estimated to be $38 \mathrm{Tg}\left(\mathrm{H}_{2}\right) \mathrm{a}^{-1}$ and $26 \mathrm{Tg}\left(\mathrm{H}_{2}\right) \mathrm{a}^{-1}$ being consumed by the soils. Globally the atmospheric sink and source budget vary between 136 and $155 \mathrm{Tg}\left(\mathrm{H}_{2}\right) \mathrm{a}^{-1}$ (Hauglustaine and Ehhalt, 2002; Novelli, 1999).

A soil moisture is coupled with a soil temperature. The high $\mathrm{H}_{2}$ deposition velocities are usually associated with the low soil moisture (Schmitt, 2009), when the soil temperature is high. A thick snow layer hinders the gas permeation into a soil surface lowering the $\mathrm{H}_{2}$ deposition velocity values (Lallo et al., 2008).

\section{Materials and methods}

The urban park near the center of Helsinki in Kumpula $\left(60^{\circ} 12^{\prime} 13^{\prime \prime} 00 \mathrm{~N}, 24^{\circ} 57^{\prime} 40^{\prime \prime} 00 \mathrm{E}\right)$ was selected for studies of soil uptake of molecular hydrogen. The vegetation consists mainly of broad-leaved trees and low grass species. The location is under the influence of local traffic and adjacent sea. The closest roads with a high traffic volume Hämeentie (44 700 cars per day) and Mäkelänkatu (45 000 cars per day) were in a minimum distance of $350 \mathrm{~m}$ and $700 \mathrm{~m}$, respectively.

\subsection{Soil chamber measurements}

The soil texture of the measurement site including surface vegetation is fine sandy till (sandy loam) according to maps provided by the Geological Survey of Finland, (a geological map available at: http://geomaps2.gtk.fi/geo/, 2009). In the south direction the soil texture changes to clay $100 \mathrm{~m}$ away from the measurement site. The detailed soil type was determined in laboratory studies (Soil Analysis Service in Mikkeli, Finland) to be gravely sandy loam (fractionated soil type) in the first $7 \mathrm{~cm}$. The $7 \mathrm{~cm}$ to $20 \mathrm{~cm}$ layer was determined as fine sandy till (coarse soil type). The field measurement setup included a stainless steel chamber $(60 \mathrm{~cm} \times 60 \mathrm{~cm})$ fixed into ground about $5 \mathrm{~cm}$ in depth. One chamber was normally used, except on 30 October 2007, when two chambers were used for comparison. The low grass species vegetation was removed inside the chamber. Both the chamber and aluminium cover was $20 \mathrm{~cm}$ in height. A small battery-operated fan was attached inside the cover to ensure mixing in the closed-chamber. The first sample was taken immediately after lowering the cover. The following samples were taken after 2 to 5 min intervals. The sampling from the closed chamber was made through a silicon tube mounted on the top of aluminium cover. A $20 \mathrm{~cm}^{3}$ plastic syringe with a three-way stop-cock valve was attached to a silicon tube during the sampling. The total length of one measurement cycle was 15 to $20 \mathrm{~min}$, which included five samples. The cover was opened after a cycle and chamber was ventilated for a few minutes. Three to four cycles were made in sequence. One ambient air sample was taken at $2 \mathrm{~m}$ height for reference purposes during one arbitrarily chosen cycle. The effect of pressure differentials were minimized using the short measurement time and the large chamber volume (Davidson et al., 2002). The soil temperature was measured using thermistors and thermocouples. The volumetric soil moisture concentration was measured by ThetaProbe ML2x sensor. Both the soil temperature and the moisture was measured four times outside of the chamber. The air samples were analyzed during the same day. The closed chamber setup was tested in a laboratory. The chamber was filled with the hydrogen in air gas, with the concentration two times higher than the ambient hydrogen mixing ratio. The hydrogen mixing ratio inside the closed chamber did not change during the $20 \mathrm{~min}$ test. The leakage from the syringes was measured and it was found to be $4 \mathrm{ppb} \mathrm{h}^{-1}$. The analysis sequence differed from the method used in the atmospheric samples. The sample inlet line was detached before syringe samples. The syringe samples were injected directly to the RGA5. At least three working standard samples were analyzed before and after the syringe samples. A response curve was made in the concentration range between the 200$2000 \mathrm{ppb}$. By plotting the mixing ratio against peak area, it is possible to construct a linear or second order fitting, which can be used for a non-linearity correction. The concentration in the chamber decreased under 200 ppb usually after $15 \mathrm{~min}$. A difference between the linear and the non-linear fit varied in the range $0.02 \mathrm{~mm} \mathrm{~s}^{-1}-0.05 \mathrm{~mm} \mathrm{~s}^{-1}$. The corresponding difference value between the non-corrected value and the second order fit was in a range $0.03 \mathrm{~mm} \mathrm{~s}^{-1}-0.06 \mathrm{~mm} \mathrm{~s}^{-1}$. 


\subsection{Atmospheric measurements}

The sampling inlet was $2 \mathrm{~m}$ above the roof of FMI (Finnish Meteorological Institute) institute building and the roof was $25 \mathrm{~m}$ above the ground level (53 ma.s.1.). The sample air was first transferred through a plastic tubing at a flow speed $10 \mathrm{~m} \mathrm{~s}^{-1}$, with a residence time ca. $1 \mathrm{~s}$. A side flow to a hydrogen analyzer was filtered with a $1.0 \mu \mathrm{m}$ Gelman filter and flushed through a stainless steel tubing to a flow restrictor and a pressure relief valve, which was adjusted to pass about $200 \mathrm{~cm}^{3} \mathrm{~min}^{-1}$ to the analyzer. A modified RGA5 instrument with RGD detector is used for the detection of molecular hydrogen. After a chromatographic separation of sample air, the molecular hydrogen passes through a mercury oxide $(\mathrm{HgO})$ bed. $\mathrm{H}_{2}$ reduces $\mathrm{HgO}$ to gaseous $\mathrm{Hg}$, which is then detected by UV absorption. The same detector is also able to detect CO. Four ambient air samples were measured during one measurement cycle, after which a working standard was included in the cycle. Each analysis took $5 \mathrm{~min}$. The system was calibrated according to four standards (scale 400$700 \mathrm{ppb}$ ) acquired from Max-Planck Institute in Jena. The reproducibility at ambient levels was obtained using calibration samples. The maximum standard deviation during the calibration was $1.5 \%$. The reproducibility working standard samples (range 915-950 ppb) of RGA5 instrument was estimated by taking into account ten consecutive samples, and it was found to be $1.1 \%$. The linearity of the RGA5 instrument was checked using a series of known mixing ratios over the atmospheric range, resulting in $R^{2}$ of 0.97 . A correlation was calculated based on the peak area versus mixing ratio. The quality of measurements was verified by the intercomparison samples of the EU-project EUROHYDROS. The description of the ambient air measurement is given in a companion article by Aalto et al. (2009). The sampling line was checked using two flask samples, taken on the roof of the institute building. Normal ambient air samples (through the inlet line) and flask samples were compared with each other. The mean of three samples was close to flask samples (difference: $2 \mathrm{ppb}$ ). The radioactive radon isotope ${ }^{222} \mathrm{Rn}$ is measured on the roof of FMI (Finnish Meteorological Institute) building. The sampling inlet is the same as used for hydrogen. The determination of radon is based on the short-lived ${ }^{222} \mathrm{Rn}$ progeny assumed to be in radioactive equilibrium. The air samples are collected onto a filter and one hour means are calculated. The analysis method is similar as described in Paatero et al. (1998) and Hatakka et al. (2003). The weather parameters were monitored with an automated weather station MILOS 500. Wind parameters were measured with a two component ultrasonic anemometer on a $32 \mathrm{~m}$ high mast next to the FMI institute building and the temperature with a shielded Pt100 detector $2.5 \mathrm{~m}$ above ground.

\subsection{Analysis of results}

\subsubsection{Soil chamber method}

The hydrogen concentration decrease inside a closedchamber follows an exponentially decreasing function. The hydrogen uptake into the soil follows first-order kinetics as mentioned by Yonemura et al. (2000). An exponential fit in Eq. (1) was applied to the concentration values.

$C(t)=\left(C_{0}-y \tau\right) \exp (-t / \tau)+y \tau$,

where $t$ is time, $C_{0}$ is the hydrogen concentration at time zero. $y$ is a production term and $\tau$ is a decay term. The deposition velocity is calculated as $v_{d}=h / \tau$, where $h$ is the chamber height. Hydrogen emission from the soil is taken into account in the production term $y$. The hydrogen mixing ratio decreased to $10-20 \mathrm{ppb}$, when the chamber was kept closed for three hours in a field test, thus the zero hydrogen production can be used. There was not any clover vegetation in the field site, which could produce hydrogen.

\subsubsection{Radon tracer method}

The radon tracer method (Levin et al., 1999; Schmidt et al., 2001) is suitable for the tropospheric determination of emission rates of trace gases (e.g. $\mathrm{H}_{2}, \mathrm{CH}_{4}, \mathrm{~N}_{2} \mathrm{O}$ ). There is a strong covariance between ${ }^{222} \mathrm{Rn}, \mathrm{CH}_{4}$ and also $\mathrm{CO}_{2}$ summer and autumn nighttime 5 mixing ratios (Levin et al., 1999). This indicates that the changes in trace gas mixing ratios originates from the variability of diurnal atmospheric conditions rather than the short term changes of trace gas emissions (Levin et al., 1999). The radon tracer method was used only during the nights, when a stable nocturnal boundary layer was formed. The height of nocturnal boundary layer is usually a few hundreds of meters, in which radon is accumulating. During the nighttime, photochemical processes affecting the hydrogen concentration are minimal since the intensity of solar irradiation in summer in Helsinki is less than $5 \%$ of the daytime values. For the method, those hours were selected when the difference between maximum and minimum hydrogen concentration was at least $5 \mathrm{ppb}$. The possibility for $\mathrm{H}_{2}$ emissions is then lowest.

The photochemical reactions, e.g. due to the hydroxyl radical formation from ozone, are not significant in the low irradiance conditions during nighttime, thus the major sink of hydrogen is soil and hydrogen is consumed in the first few centimeters of the soil (Schmitt et al., 2008), while the only source process for ${ }^{222} \mathrm{Rn}$ is the exhalation from the soil. The $\mathrm{H}_{2}$ flux can be calculated using Eq. (2).

$j_{\mathrm{H} 2}=j_{\mathrm{Rn}} \frac{\Delta c_{\mathrm{H} 2}}{\Delta c_{\mathrm{Rn}}}\left(1-\frac{\lambda_{\mathrm{Rn}} c_{\mathrm{Rn}}}{\Delta c_{\mathrm{Rn}} / \Delta t}\right)$

if the radon flux $j_{\mathrm{Rn}}$ is known (Schmidt et al., 2001). The $\Delta c_{\mathrm{H} 2} / \Delta c_{\mathrm{Rn}}$ is a ratio between the hydrogen concentration difference, $\Delta c_{\mathrm{H} 2}$ and radon concentration difference, $\Delta c_{\mathrm{Rn}}$. 
$\lambda_{\mathrm{Rn}} c_{\mathrm{Rn}}(t)$ is the decay rate for radon including the radioactive decay constant $\lambda_{\mathrm{Rn}}$ and the radon concentration $c_{\mathrm{Rn}}$. For the radon tracer method calculations, only those nights were accepted when the hydrogen mixing ratio decreased more than $5 \mathrm{ppb}$ and the radon activity concentration increased more than $0.6 \mathrm{~Bq} \mathrm{~m}^{-3}$ between 23:00 and 05:00 LT. Only high correlation $R^{2}>0.8$ events, which had five or six hours of data were selected.

\subsubsection{Two-dimensional model}

The hydrogen deposition velocities were also determined by a two-dimensional model. The model was built for support, comparison and verification of other methods described earlier. It has been applied for hydrogen soil deposition studies in Northern Finland by Lallo et al. (2009). The model is based on the three-dimensional atmospheric model described in Aalto et al. (2006). The variation in vegetation, land use and topography is suppressed to one specified type to gain faster simulation run times, while the surface fluxes are inverted from atmospheric concentration observations. The uncertainty of fixing the vegetation to one specific type is small compared to the uncertainty which is related to the estimation of the boundary layer in the two-dimensional model. A $5 \mathrm{~m}$ thick surface layer was built in the model, where the soil acted as a passive solid and fluxes were defined only in the air-soil interface of the model. The purpose of the $5 \mathrm{~m}$ surface layer is created for the calculations of the energy balance. This requires realistic values for the soil density and the thermal conductivity. The modeled layer could also be thinner. The model was run with setup of a $3 \mathrm{~km}$ vertical extent (12 layers) and a horizontal extent of $10 \mathrm{~km}$ (10 grid boxes), which gives a resolution of $1 \mathrm{~km}$. During a simulation run, a user is not allowed to make any adjustment, all changes are made by the model itself. The commercial fluid dynamics software Fluent ${ }^{\circledR}$ (CFD Flow Modeling Software and Solutions from Fluent, 2009) was used to solve fluxes and concentrations of radon and hydrogen. The mass and energy exchange formulations in the soil-air surface were modeled by the user defined codes added to the model (Aalto et al., 2006). The necessary boundary conditions were also given based on the local observations. The following boundary conditions are included in the two-dimensional model: A hydrogen and a radon outflow profile is transferred to the inflow profile (a periodic boundary condition). Weather parameters (air temperature, humidity, atmospheric pressure, wind speed) are controlled in the inflow, where adjustments were made in $5 \mathrm{~min}$ steps. These were also local observations. The two-dimensional model is used to estimate hydrogen deposition velocity using the meteorological input values and hydrogen mixing ratio. In addition same twodimensional model is used separately for the estimation of radon exhalation. Only the radon flux is estimated based on the radon concentration measurements (initial profile). After that, model changes the radon concentrations according to model controls.

The turbulence inside the domain was simulated using the standard K-epsilon theory by Launder and Spalding (1972). The model equations for energy, turbulence, fluid and species transport were solved in a segregated mode. The model allowed changes to the initial value of meteorological pressure i.e. the model was non-hydrostatic. As in the case of radon tracer method, the nighttime simulations were made to avoid the indirect photochemical degradation of hydrogen. The model was initialized few hours before the selected time range to achieve a balanced state. During the simulation, the hydrogen and radon outflow vertical profile from the preceding time step was used as a new input to the following time steps. The deposition velocities and the radon exhalation rates were solved at every time step to let the modeled outflow concentration meet the observed concentrations at Kumpula site. The hydrogen and radon surface fluxes were thereby inverted from the concentration observations. Simulation results consist of stabilized flux values obtained at the end of each simulation hour. The model minimizes the difference between the modeled and observed values. For hydrogen, only those nights were accepted when there was at least four hours of monotonous increase in radon and decrease in hydrogen mixing ratios. In the case of radon, also nights with no hydrogen decrease were accepted. These selection criteria are somewhat different from radon tracer method and result in a larger number of events. Our aim was to obtain an extensive data set especially for radon, so that we could estimate the radon exhalation rate separately for winter and summer.

The boundary layer height simulated by the twodimensional model was compared to the ceilometer data at about $2 \mathrm{~km}$ distance from the Kumpula site. The model produced a turn in the potential temperature profile, which was interpreted as the top of the boundary layer. On 13 July 2007, at 02:00 to 04:00 LT the turn occurred at $124 \mathrm{~m}$ height, while on 18 July 2007 at 00:00 to 05:00 LT it appeared at the next model level, $198 \mathrm{~m}$ above ground. The ceilometer boundary layer estimate showed high variability for these nights, which could not be reproduced by the model. This was observed on 13 July 2007, 80-240 m, and on 18 July 2007, $310-590 \mathrm{~m}$, respectively. On the contrasting winter night conditions $\left(-15^{\circ} \mathrm{C}\right)$ in 10 February 2007 , the model simulated the first inversion at $75 \mathrm{~m}$ model level, and second at $198 \mathrm{~m}$ level, while the ceilometer results indicated 70-200 m for a boundary layer (BL) height. Generally, when the observations showed lower BL height, also the model indicated a shallow BL. However, the model results were in the lower end of the range given by observations, and therefore the simulated BL height may be somewhat too low. This would result in an underestimation of the inverted hydrogen and radon fluxes. 


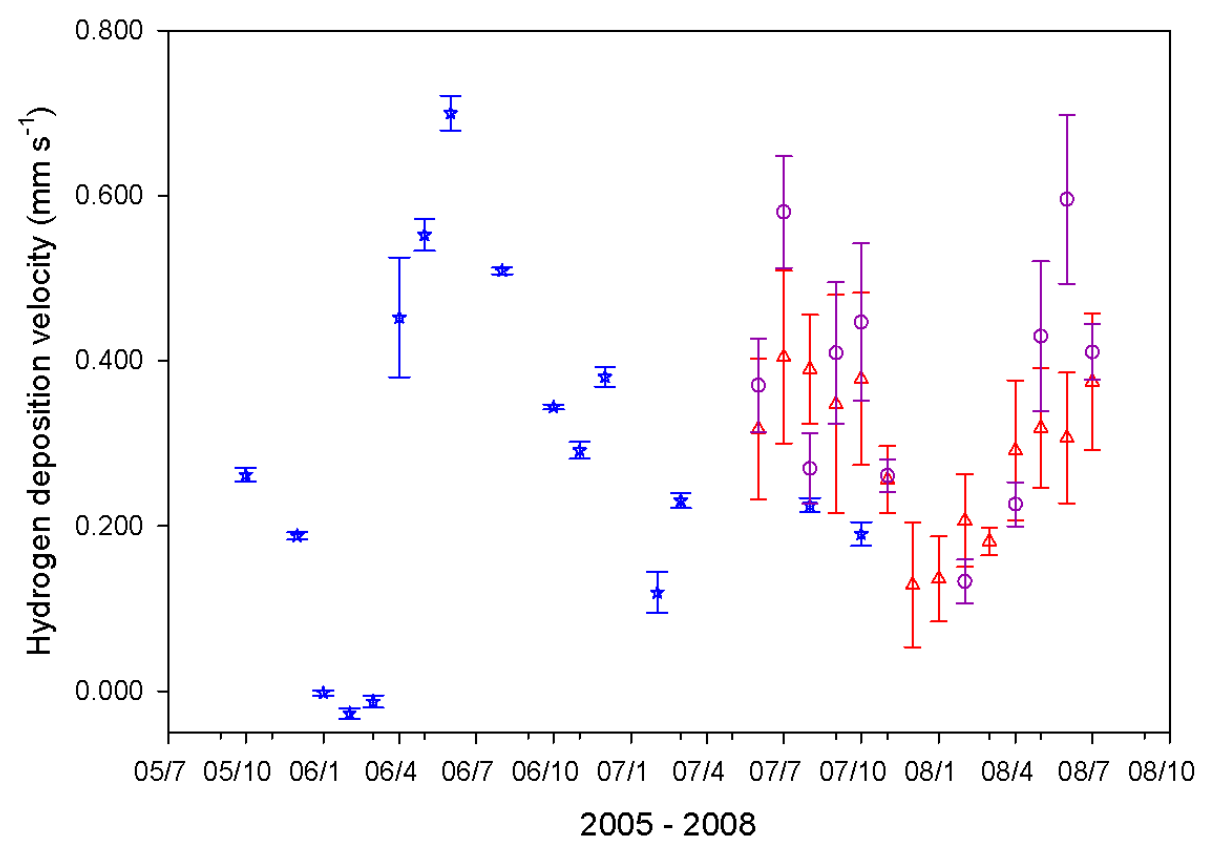

Fig. 1. Hydrogen deposition velocity $\left(v_{d}\right)$ mean values from the chamber measurements, and using radon tracer method and two-dimensional model. The $v_{d}$ values are presented as mean \pm standard error of the mean (SE).

\section{Results}

\subsection{Hydrogen deposition velocities from soil chamber measurements}

The chamber measurements were performed between 28 October 2005 and 30 October 2007 at the urban park site in Kumpula. The automatic weather system (AWS) data collected from Helsinki area (Kaisaniemi and Kumpula) was used in the interpretation of chamber and model results. Hydrogen $v_{d}$ values are shown in Fig. 1 (blue stars). The lowest close to zero $v_{d}$ values were measured in January to March 2006 and highest $0.70 \pm 0.02 \mathrm{~mm} \mathrm{~s}^{-1}$ on 15 June 2006. The winter (13 field days from November to April) $v_{d}$ values ranged from $0.00 \mathrm{~mm} \mathrm{~s}^{-1}$ to $0.45 \mathrm{~mm} \mathrm{~s}^{-1}$ with mean value of $0.20 \pm 0.05 \mathrm{~mm} \mathrm{~s}^{-1}$ and in summer ( 8 field days from May to October) from $0.13 \mathrm{~mm} \mathrm{~s}^{-1}$ to $0.70 \mathrm{~mm} \mathrm{~s}^{-1}$ (Table 1) with mean value of $0.38 \pm 0.07 \mathrm{~mm} \mathrm{~s}^{-1}$. The lowest values occurred when snow covered the ground, as indicated by Lallo et al. (2008). The highest $v_{d}$ value $\left(0.18 \pm 0.04 \mathrm{~mm} \mathrm{~s}^{-1}\right)$ with permanent snow cover was measured on 2 February 2007 (Fig. 2). Snow depth was then $16 \mathrm{~cm}$, soil temperature $+0.5^{\circ} \mathrm{C}$ and soil volumetric water content $0.27 \mathrm{~m}^{3} \mathrm{~m}^{-3}$. When snow depth exceeded $20 \mathrm{~cm}, v_{d}$ values were close to zero. When snow layer thickness was between $10 \mathrm{~cm}$ and $20 \mathrm{~cm}, v_{d}$ mean values were lower than $0.20 \mathrm{~mm} \mathrm{~s}^{-1}$.

Hydrogen $v_{d}$ values are shown together with corresponding air and soil temperatures in Fig. 3a and b (stars). There is a large scatter in $v_{d}$, but it tends to get lower values in freezing temperatures. In Fig. $3 c$ hydrogen $v_{d}$ is plotted against soil volumetric water content showing lower values at high soil moistures. Higher $v_{d}$ values (above $0.50 \mathrm{~mm} \mathrm{~s}^{-1}$ ) were only recorded in drought conditions, when soil moisture was between $0.10-0.25$ below and soil temperature was $10^{\circ} \mathrm{C}$ or higher. Low $v_{d}$ values (below $0.20 \mathrm{~mm} \mathrm{~s}^{-1}$ ) were often associated with subzero or close to zero values and snow cover (see Fig. 2). The soil temperature was then usually below $4^{\circ} \mathrm{C}$. According to measurement records, heavy rain showers decreased soil uptake when there had been precipitation within three days before. An intensive thundershower $(13.8 \mathrm{~mm})$ two days before hindered the soil uptake on 24 August 2007 (Fig. 3b), lowering $v_{d}$ to $0.13 \pm 0.01 \mathrm{~mm} \mathrm{~s}^{-1}$, which was the lowest summer time $v_{d}$ value in the whole measurement period. On 2 August 2007 weather conditions were favoring strong soil uptake. The soil temperature and the volumetric water content was $15^{\circ} \mathrm{C}$ and $0.24 \mathrm{~m}^{3} \mathrm{~m}^{-3}$ respectively, but only $0.33 \pm 0.01 \mathrm{~mm} \mathrm{~s}^{-1}$ was recorded (Fig. 3b). Three days before $20.4 \mathrm{~mm}$ rain was recorded. The total amount of $24.1 \mathrm{~mm}$ precipitation was recorded on 31 October 2006 with $v_{d}$ value of $0.34 \mathrm{~mm} \mathrm{~s}^{-1}$. Compared to high summer values recorded in 2006, soil uptake was significantly reduced. The soil volumetric water content was $0.41 \mathrm{~m}^{3} \mathrm{~m}^{-3}$. There was a four-month drought in 2006 in Helsinki area, when high $v_{d}$ values of $0.509 \pm 0.004 \mathrm{~mm} \mathrm{~s}^{-1}$ (2 August), $0.55 \pm 0.02 \mathrm{~mm} \mathrm{~s}^{-1}$ (31 May) $0.70 \pm 0.02 \mathrm{~mm} \mathrm{~s}^{-1}$ (15 June) were measured (Fig. 3b and c, red stars). Soil volumetric water content values were between $9 \mathrm{~m}^{3} \mathrm{~m}^{-3}$ and $25 \mathrm{~m}^{3} \mathrm{~m}^{-3}$, while the typical soil volumetric water content 
Table 1. Hydrogen deposition velocities measured and modeled with different methods.

\begin{tabular}{llll}
\hline Reference & Method & Comments & $v_{d}\left(\mathrm{~mm} \mathrm{~s}^{-1}\right)$ \\
\hline this paper & chamber & $\begin{array}{l}\text { May to October } \\
\text { November to April }\end{array}$ & $\begin{array}{l}0.13-0.7 \\
0.00-0.45 \\
\text { drought }(2006)\end{array}$ \\
& & $\begin{array}{l}0.50-0.70 \\
<0.20\end{array}$ \\
\hline this paper & radon tracer & May to October & $0.14-0.93$ \\
& & November to April & $0.13-0.27$ \\
\hline this paper & two-dimensional model & May to October & $0.13-0.61$ \\
& & November to April & $0.12-0.33$ \\
\hline Hammer and Levin, & radon tracer & urban/suburban & $0.1-0.8$ \\
2009 & & environment & \\
\hline Rahn et al., 2002 & concentration & burn boreal forest & $0.44^{\mathrm{a}}$ \\
& gradients & mature boreal forest & $0.73^{\mathrm{a}}$ \\
\hline $\begin{array}{l}\text { Smith-Downey et al., } \\
2008\end{array}$ & chamber & forest & $0.63^{\mathrm{a}}$ \\
& & desert & $0.51^{\mathrm{a}}$ \\
& & marsh & $0.35^{\mathrm{a}}$ \\
\hline
\end{tabular}

a mean deposition velocities

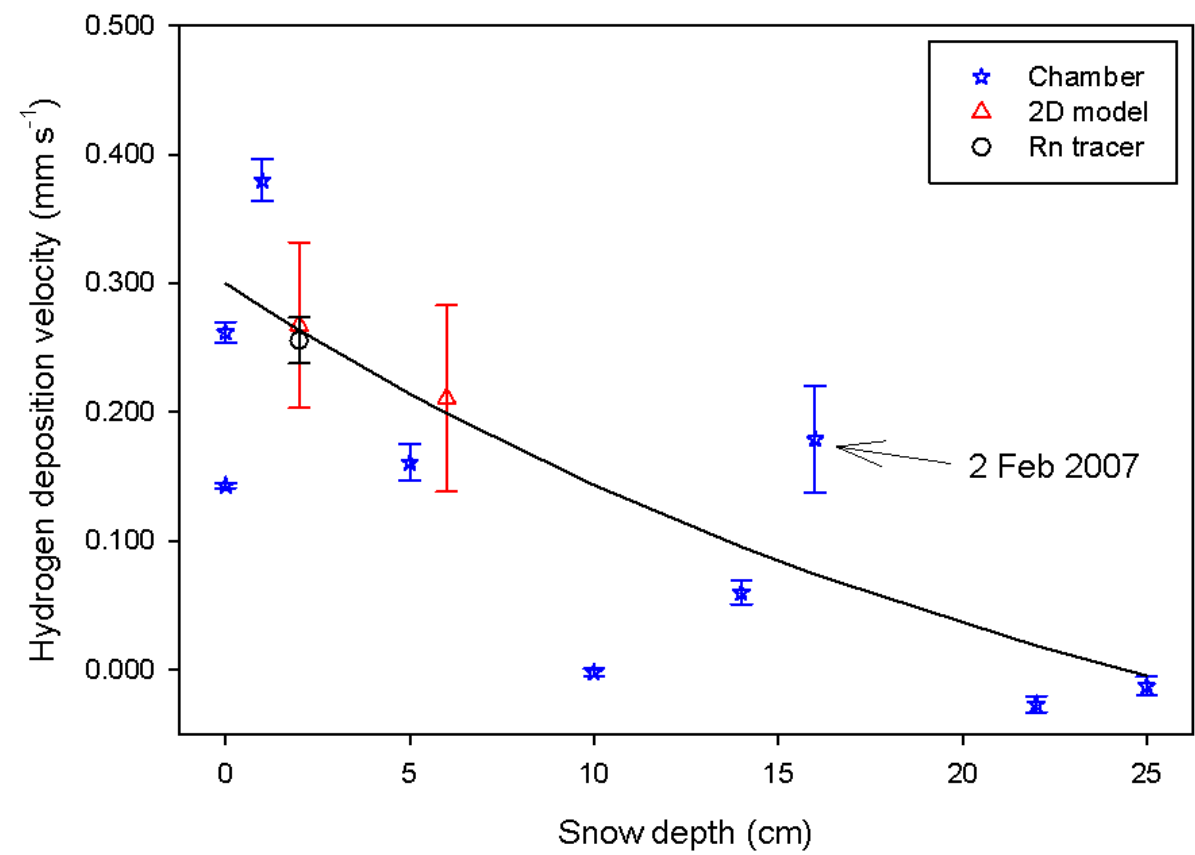

Fig. 2. The effect of snow depth to soil uptake rate. R2, i.e. squared correlation coefficient, is 0.62 .

values obtained in the field measurement were higher than $0.29 \mathrm{~m}^{3} \mathrm{~m}^{-3}$. The cumulative rain sum between 26 May and 29 September 2006 was only $51.6 \mathrm{~mm}(287.3 \mathrm{~mm}$ in 2007 and $265.2 \mathrm{~mm}$ in 2008) in Helsinki area. In May 2008 the rain sum was significantly lower $(7.5 \mathrm{~mm})$ than in May 2006 (41.6 mm) and 2007 (58.9 mm) (Fig. 4).
All error bars were calculated as the standard error of the mean $(\sigma / \sqrt{ } \mathrm{n})$, except otherwise mentioned. The chamber error bars were calculated by averaging all three or four repetitions. Sensitivity studies related to syringe sampling from the chamber have been made in a 3-h field test. Three consecutive samples were taken to represent one sampling time point. According to this test all points were well distributed 

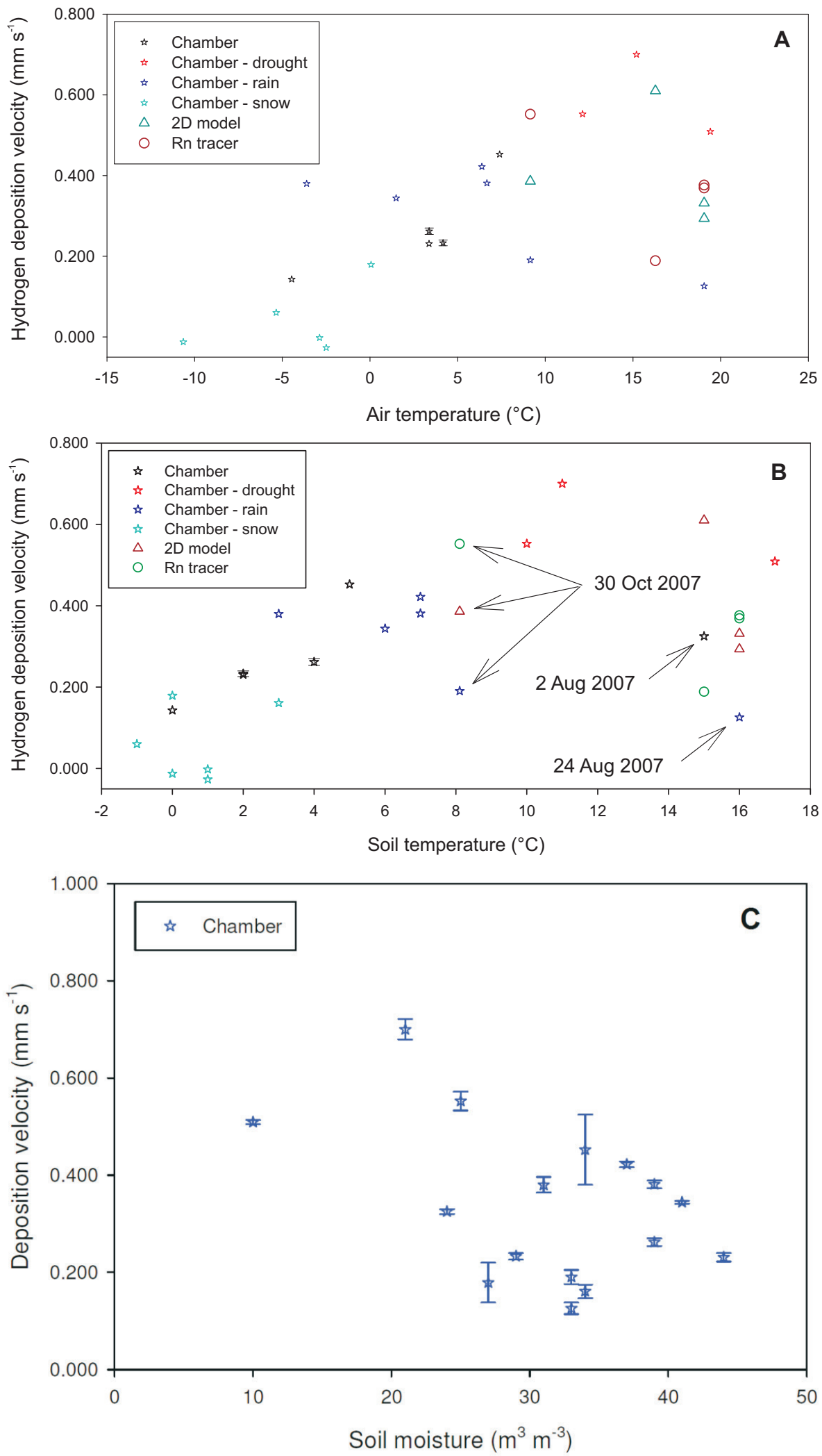

Fig. 3. The dependency of measured and four modeled hydrogen deposition velocity values (a) to air (b) soil temperature of chamber measurements and (c) the dependency of measured hydrogen deposition velocity to soil volumetric water content of chamber measurements. 


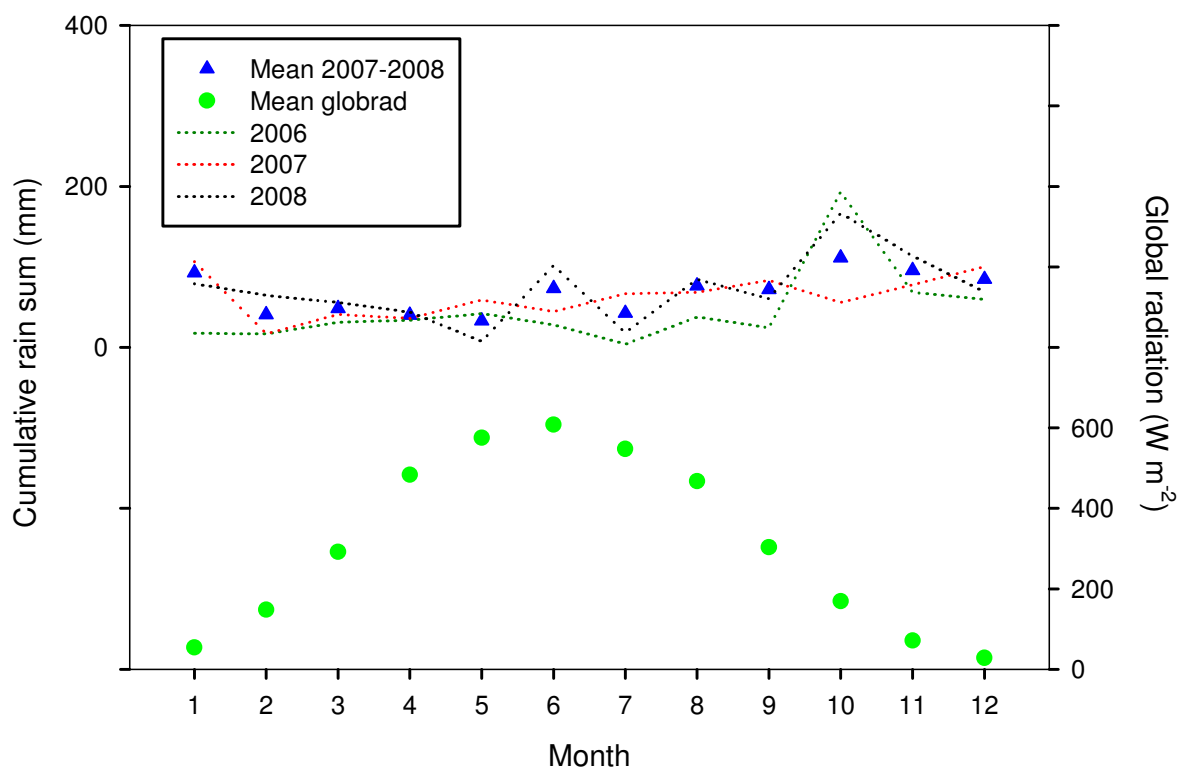

Fig. 4. Biannual global radiation average obtained at 12:00 UTC and biannual cumulative monthly precipitation 2007-2008 and monthly rain sum for years 2006 to 2008 .

along an exponentially decreasing curve. Soil temperature is a slowly changing feature and it takes usually several days to see the changing trend. This is also the case with the soil moisture.

\subsection{Hydrogen deposition velocities and radon exhalation rates from two-dimensional model simulations}

The two-dimensional model results covered the time period between June 2007 and July 2008, when atmospheric hydrogen mixing ratios were continuously measured at Kumpula. The modeled winter (13 nights) $v_{d}$ values ranged from $0.12 \mathrm{~mm} \mathrm{~s}^{-1}$ to $0.33 \mathrm{~mm} \mathrm{~s}^{-1}$ with mean value of $0.22 \pm 0.02 \mathrm{~mm} \mathrm{~s}^{-1}$ and in summer (35 nights) from $0.13 \mathrm{~mm} \mathrm{~s}^{-1}$ to $0.61 \mathrm{~mm} \mathrm{~s}^{-1}$ with mean value of $0.35 \pm 0.02 \mathrm{~mm} \mathrm{~s}^{-1}$ (Table 1). The modeled mean radon exhalation rate in winter (from November to April) was $22 \pm 1 \mathrm{~Bq} \mathrm{~m}^{-2} \mathrm{~h}^{-1}$ and in summer (from May to October) $45 \pm 3 \mathrm{~Bq} \mathrm{~m}^{-2} \mathrm{~h}^{-1}$ with highest values occurring in $\mathrm{Au}-$ gust 2007 (Fig. 5). The highest exhalation rates were observed during northerly winds when air masses traveled above continent and captured high radon activities before arrival to the site. The northerly-northeasterly winds dominated during August 2007 high radon exhalation nights. Generally, the conditions were favorable for radon exhalation in summer when the soil was not saturated with water despite of short rain periods which lowered radon exhalation rates. Radon exhalations are depicted against one week cumulative precipitation in Fig. 6a. Pearson product moment correlation for Fig. $6 \mathrm{a}$ is -0.321 . The correlation is significant at the
0.01 level (2-tailed). Over $100 \mathrm{~Bq} \mathrm{~m}^{-2} \mathrm{~h}^{-1}$ emission values were reached in dry conditions, while $25 \mathrm{~mm}$ precipitation lowered the radon emission down to $50 \mathrm{~Bq} \mathrm{~m}^{-2} \mathrm{~h}^{-1}$. Correspondingly, one week dry period raised the hydrogen soil uptake to hydrogen deposition velocity values up to $0.7 \mathrm{~mm} \mathrm{~s}^{-1}$ and $25-30 \mathrm{~mm}$ precipitation decreased the $v_{d}$ values down to about $0.3-0.4 \mathrm{~mm} \mathrm{~s}^{-1}$ (Fig. 6b) according to all three methods. Pearson product moment correlation for Fig. $6 \mathrm{~b}$ is -0.271 . Correlation is significant at the 0.05 level (2-tailed), when outliers were excluded according to standard deviation. The winter soils were typically moister than the summer soils due to a lower evapotranspiration regulated by a global irradiation, which had a maximum of over $600 \mathrm{~W} \mathrm{~m}^{-2}$ in June, while in December less than $100 \mathrm{~W} \mathrm{~m}^{-2}$ (Fig. 4) was reached (see also Vesala et al., 2006). This can be seen in the yearly cycle of radon exhalation rates in Fig. 5, as well as in the hydrogen results in Fig. 1 (all methods), where lower $v_{d}$ values were recorded during winter.

\subsection{Hydrogen deposition velocities from radon tracer method}

The radon tracer method results covered the time period between June 2007 and July 2008 (Table 1). According to the radon tracer method, in winter (November to April, 5 nights), the modeled $v_{d}$ values ranged from $0.13 \mathrm{~mm} \mathrm{~s}^{-1}$ to $0.27 \mathrm{~mm} \mathrm{~s}^{-1}$ with a mean value of $0.22 \pm 0.02 \mathrm{~mm} \mathrm{~s}^{-1}$ and in summer (May to October, 32 nights), the modeled $v_{d}$ values ranged from $0.14 \mathrm{~mm} \mathrm{~s}^{-1}$ to $0.93 \mathrm{~mm} \mathrm{~s}^{-1}$ with a mean value of $0.43 \pm 0.04 \mathrm{~mm} \mathrm{~s}^{-1}$ (Fig. 1, dark pink circles). The radon tracer method is dependent on the radon exhalation 


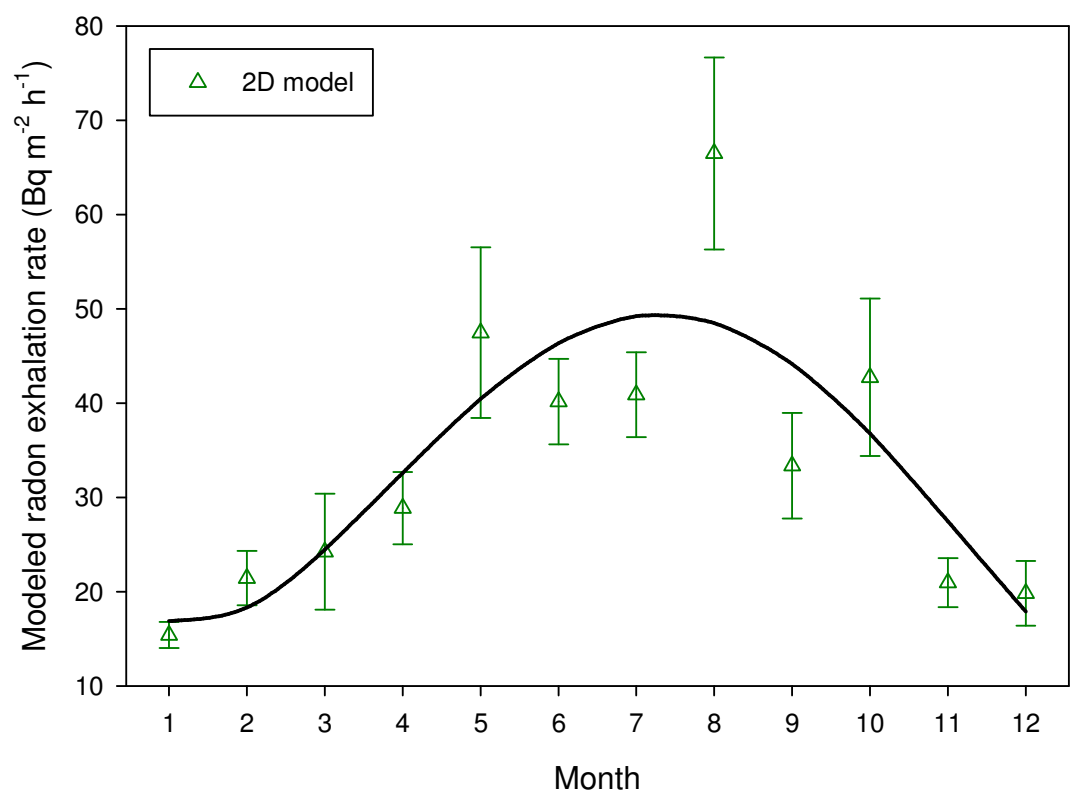

Fig. 5. Two-dimensional model results for ${ }^{222} \mathrm{Rn}$ exhalation rate $j \mathrm{Rn}$.

rate, which was estimated by the two-dimensional model. A monthly mean was calculated by fitting a smooth curve to modeled radon exhalation rates (Fig. 5). The annual cycle of hydrogen deposition velocities was similar than the one simulated with the two-dimensional model, but there were cases when the radon tracer method indicated higher values than the two-dimensional model, which can be seen in Figs. 1 and $6 \mathrm{~b}$. The range of both the radon tracer method and the twodimensional model results was in good agreement with the chamber results.

All methods delivered results on 30 October 2007, the radon tracer method and the two-dimensional model $v_{d}$ values were $0.55 \pm 0.16 \mathrm{~mm} \mathrm{~s}^{-1}$ and $0.39 \pm 0.18 \mathrm{~mm} \mathrm{~s}^{-1}$ respectively, while the soil chambers indicated a $v_{d}$ of only $0.19 \pm 0.01 \mathrm{~mm} \mathrm{~s}^{-1}$. The soil water content was $0.33 \mathrm{~m}^{3} \mathrm{~m}^{-3}$ and the soil temperature was $9^{\circ} \mathrm{C}$ (Fig. 3b). There was a rain during 30 October 2007 which may have affected the soil chamber result, measured at midday, while the other estimates refer to earlier nighttime observations from drier soils. In general, the October 2007 rain sum was significantly lower, $56 \mathrm{~mm}$, than in October 2006, $183.6 \mathrm{~mm}$ and in 2008, $166.6 \mathrm{~mm}$. The results also had a lot of statistical variation. The difference between the radon tracer method and the twodimensional model was probably due to the choice of data. For example, if only three hours with the largest change in hydrogen and radon are selected from the two-dimensional model simulations, the resulting $v_{d}$ increases to $0.65 \mathrm{~mm} \mathrm{~s}^{-1}$.

\section{Discussion}

\subsection{Radon exhalation rate}

The radon tracer method is dependent on the pre-calculated radon exhalation rate $j_{R n}$, which is based on regional radon emission estimates. The radon exhalation rates were measured by Dörr and Münnich (1990) in cultivated fields and undisturbed forest soils. The fluxes were in the range $500 \mathrm{dpm} \mathrm{m}^{-2} \mathrm{~h}^{-1}$ and $6500 \mathrm{dpm} \mathrm{m}^{-2} \mathrm{~h}^{-1}(8-$ $108 \mathrm{~Bq} \mathrm{~m}^{-3}, 1 \mathrm{dpm}=1 / 60 \mathrm{~Bq}$ ) in West Germany and the average value was $3200 \mathrm{dpm} \mathrm{m}^{-2} \mathrm{~h}^{-1}\left(53 \mathrm{~Bq} \mathrm{~m}^{-2} \mathrm{~h}^{-1}\right)$. Szegvary et al. (2007) measured exhalation rates at 8 locations in southern Finland by using soil chambers. There were significant variations in radon exhalation rates, which were between $51 \mathrm{Bqm}^{-2} \mathrm{~h}^{-1}$ and $134 \mathrm{Bqm}^{-2} \mathrm{~h}^{-1}$ including one peak value of $189 \mathrm{Bqm}^{-2} \mathrm{~h}^{-1}$. An average value of $100 \pm 17 \mathrm{~Bq} \mathrm{~m}^{-2} \mathrm{~h}^{-1}$ was obtained when eight locations in southern Finland was included to calculations ( $88 \mathrm{~Bq} \mathrm{~m}^{-2} \mathrm{~h}^{-1}$ if peak value was excluded). Levin et al. (2002) measured radon exhalation rates for moist boreal forest using closed-chamber technique at Fyodorovskoye in Russia. ${ }^{222} \mathrm{Rn}$ exhalation rates were in the range $3.3 \mathrm{~Bq} \mathrm{~m}^{-2} \mathrm{~h}^{-1}$ to $7.9 \mathrm{~Bq} \mathrm{~m}^{-2} \mathrm{~h}^{-1}$, while water table depth were from $5 \mathrm{~cm}$ to about $70 \mathrm{~cm}$. Strong relation between water table depth and radon fluxes was found. (Levin et al., 2002; Conen and Robertson, 2002). Conen and Robertson (2002) measured ${ }^{222} \mathrm{Rn}$ flux using a closed-chamber technique. They found that radon flux was at the highest in mineral soil type with no humic layer, decreasing towards more humic and organic soil type. A modeled radon exhalation rate can also be used as an input to the radon 

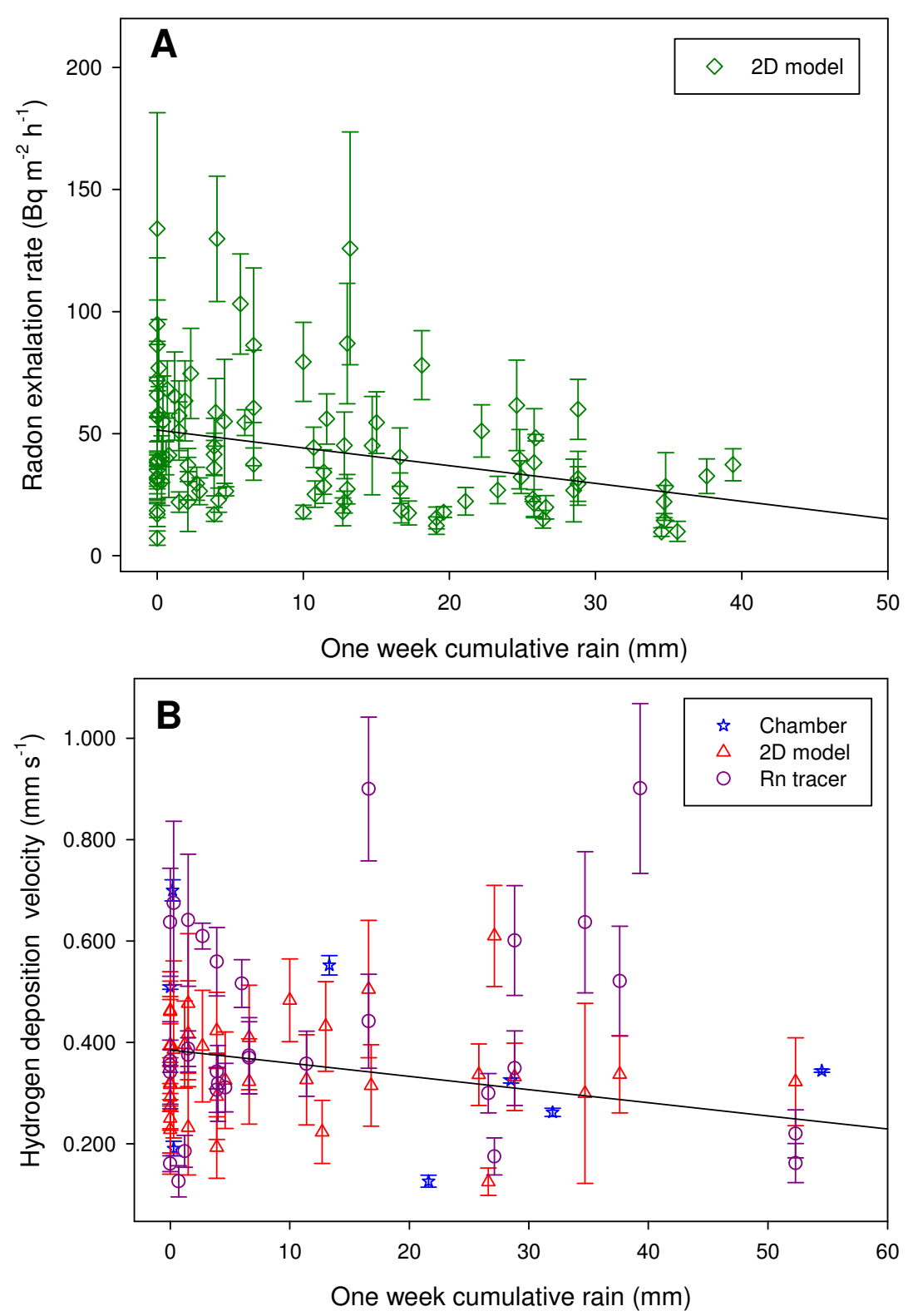

Fig. 6. The effect of one week cumulative rain (summer points) to (a) the radon exhalation $(p<0.01)$ and (b) the modeled and measured hydrogen deposition velocities $(p<0.05)$.

tracer method. Our radon fluxes simulated with the twodimensional model were lower in comparison to the southern Finland and Germany chamber results, but higher in comparison to Fyodorovskoye. The highest values were obtained during northerly winds from the continent. Thus the proximity of the sea may have a lowering effect on the mean values. Also, the two-dimensional model can provide only a crude estimate of the boundary layer height which has a direct effect on the magnitude of the inverted flux. However, it is not probable that the mean radon fluxes are heavily underestimated.
When a nocturnal nighttime layer is formed, radon accumulates in the layer. In daytime, the boundary layer height increases and radon is mixed in to larger volume and it is more unevenly distributed due to solar heating. Most probably slow inversion layer development enables conditions, where radon had aged couple of hours and thus equilibrium condition could be assumed. According to the radon tracer method the hydrogen deposition velocity values are proportional to the radon exhalation rate (Eq. 2) and the method would yield unrealistically high deposition velocities if radon fluxes were multiplied by e.g. a factor of two. The hydrogen flux calculation in the two-dimensional model is dependent 
on the boundary layer height estimation. This could produce error of $10 \%$ to a few tens. A minor source of error is the vegetation layer, which is modeled as a single uniform layer.

\subsection{Comparison between the methods}

The results of chamber measurements were in the same range with the earlier measurements made in the boreal zone (Rahn et al., 2002; Smith-Downey et al., 2008). According to the chamber measurement results, hydrogen soil deposition increased on May to August 2006 after a long drought. During that time the soil volumetric water content varied between $0.09 \mathrm{~m}^{3} \mathrm{~m}^{-3}$ and $0.25 \mathrm{~m}^{3} \mathrm{~m}^{-3}$, which was significantly lower than typical values $\left(0.29 \mathrm{~m}^{3} \mathrm{~m}^{-3}\right.$ to $0.41 \mathrm{~m}^{3} \mathrm{~m}^{-3}$ ) recorded in 2005 and $2007-2008$. The highest $v_{d}$ values $0.5 \mathrm{~mm} \mathrm{~s}^{-1}$ to $0.7 \mathrm{~mm} \mathrm{~s}^{-1}$ were measured in high soil temperature conditions from $10^{\circ} \mathrm{C}$ to $17^{\circ} \mathrm{C}$, which was usually recorded from May to August. Negligibly small $v_{d}$ values were measured, when air and soil temperatures were near-zero and the soil surface was snow covered. The soil volumetric water content was usually higher in winter than in summer. The dependency of $v_{d}$ to the soil volumetric water content (in this study $R^{2}$ was 0.47 ) might be more important than to the soil temperature (Schmitt et al., 2009). The dryness of soil is in correlation with the high soil temperature. The high soil water content effectively hindered the hydrogen diffusion into ground. The modeled hydrogen deposition values were compared against chamber measurements and using several parameters, such as air/soil temperature and soil volumetric water content (Fig. 3a, b, c). The modeled and measured $v_{d}$ values were in good agreement with each other and their annual cycles were similar (Fig. 1). The radon tracer $v_{d}$ values were distributed more evenly in summer time (May to October), yielding values from $0.14 \mathrm{~mm} \mathrm{~s}^{-1}$ to $0.93 \mathrm{~mm} \mathrm{~s}^{-1}$. The $v_{d}$ values of the two-dimensional model were distributed to more narrow range $\left(0.13 \mathrm{~mm} \mathrm{~s}^{-1}\right.$ to $\left.0.61 \mathrm{~mm} \mathrm{~s}^{-1}\right)$ than the radon tracer method (Fig. 1). In winter time both the radon tracer and the two-dimensional model produced $v_{d}$ values lower than $0.33 \mathrm{~mm} \mathrm{~s}^{-1}$. Within the modeled period the lowest air temperature was $-5^{\circ} \mathrm{C}$ and highest $21^{\circ} \mathrm{C}$. Among both models, the results did not show clear temperature dependency above zero temperatures. Hammer and Levin (2009 and references therein) used also the radon tracer method for the estimation of nocturnal soil uptake rate and respective hydrogen deposition velocities in urban/suburban environment. The estimated $v_{d}$ values ranged from $0.1 \mathrm{~mm} \mathrm{~s}^{-1}$ to $0.8 \mathrm{~mm} \mathrm{~s}^{-1}$, which is close to our results. The disturbance of pressure differentials cannot totally avoid, but the effect of these can be minimized using a short measurement time and a large chamber volume (Davidson et al., 2002). For this reason, chamber was kept closed only $15 \mathrm{~min}$ and a large closed-volume (about 100 L) chamber was used. During the sampling, only about $0.4 \mathrm{dm}^{3}$ is removed from the chamber headspace. When examining the deposition velocity values of consecutive measurements, all the values were scattered randomly and usually all values were close to each other. Systematic trends between the repetitive measurements were not observed. In addition, according to Hutchinson and Livingston (2001) repetitive chamber measurements is not a major source of error.

\subsection{Precipitation and $v_{d}$}

A strong solar irradiation during summer (May to July) above $600 \mathrm{~W} \mathrm{~m}^{-2}$ is capable of drying the top soil layer allowing higher soil uptake. In fall, low solar irradiation and more frequent rain periods keep the soil volumetric water content level high. The chamber measurements made on rainy weather conditions indicate low hydrogen deposition rates. The field measurement made on 24 August 2007 was affected by intensive thunderstorm two days before. All field measurements where $v_{d}$ was less than $0.2 \mathrm{~mm} \mathrm{~s}^{-1}$ were snow results, (Fig. 3a, b) except 24 August and 30 October 2007. However, the soil volumetric water content at 24 August was not higher than typical values. There is not a single factor, which fully explains the lowest $v_{d}$ value, but the soil surface may have compacted after rain, hindering gas diffusion into ground. On the other hand high $v_{d}$ values were occasionally measured in high soil volumetric water content conditions. In these cases, the probe may have overestimated the soil volumetric water content, especially when the soil surface was moist due to small amount of rain. In snowy winter conditions, $v_{d}$ values were small at sub-zero temperatures (Fig. 2). This is supported by results of Lallo et al. (2008), who made field measurements in winter with snow cover. Snow cover hinders the gas diffusion into ground resulting in lower $v_{d}$ as shown in Fig. 2. Also when thicker snow layer is formed, it becomes more layered due to changing weather conditions. The permeability of snow differs from the gas permeability of thinner snow layer (Albert and Schultz, 2002). Yonemura et al. (2000) found, based on modeling and measurements, that diffusion into soil is an important factor controlling hydrogen and carbon monoxide soil uptake. The comparison of $v_{d}$ values and radon exhalation rates with rain records showed a decreasing trend towards increased one week cumulative precipitation. The decreased soil uptake rate and radon exhalation was possibly due to higher soil volumetric water content. Precipitation has effects to short-term variations to ${ }^{222} \mathrm{Rn}$ flux (Szegvary et al., 2007). Szegvary et al. (2007) found during the long-term measurements (June to November 2006) in Basel, that while the prolonged dry period decreased the soil volumetric water content, the ${ }^{222} \mathrm{Rn}$ flux increased about $100 \%$ until the beginning of August. The ${ }^{222} \mathrm{Rn}$ flux was enhanced due to increased diffusion and air-filled porosity and decreased soil volumetric water content. Later measurements on September in three rainy days showed that ${ }^{222} \mathrm{Rn}$ flux decreased immediately with the beginning of precipitation, preventing ${ }^{222} \mathrm{Rn}$ diffusion into atmosphere (Szegvary et al., 2007). In Finland there was a dry period from June to August 2006. The lowest soil volumetric 
water content in conjunction with high temperature increased the hydrogen soil uptake, $v_{d}$ values were $>0.5 \mathrm{~mm} \mathrm{~s}^{-1}$, due to enhanced diffusion into the soil layers. Schery et al. (1984) found also that radon flux and its diffusion into ground is reduced in rainy conditions due to capping effect of the top soil layer. The water-filled porosity is increased, when the soil is moistened by water leading to the retarded gas emissions. The soil exhalation values show significant spatial variation, correlated to soil water content. The radon tracer method is sensitive to changes in radon emissions and its applicability is regional. Radon gas is accumulating in to a nighttime boundary layer. For this reason a stable nocturnal layer and low wind conditions are needed. Typical range is about tens of kilometers to over one hundred. The twodimensional model covers also much larger area (horizontal extend $10 \mathrm{~km}$ ) than the chamber measurements, which determines the soil uptake rate at a specific point. The uncertainty range of the radon tracer and the two-dimensional results in hydrogen $\mathrm{v}_{d}$ values are larger than the chamber $\mathrm{v}_{d}$ values. The results of simulation methods are between the range $0.00 \mathrm{~mm} \mathrm{~s}^{-1}$ to $0.93 \mathrm{~mm} \mathrm{~s}^{-1}$, which follows also the results of chamber based $\mathrm{v}_{d}$ values. Only the two highest radon tracer points $\left(0.93 \mathrm{~mm} \mathrm{~s}^{-1}\right)$ are higher than the chamber results. Although error bars are larger in both models, model points are comparable with the chamber results. The two-dimensional model estimates the boundary layer height. The uncertainty of flux values calculated by the model varies from $10 \%$ to a few tens. This affects to the hydrogen flux estimation. The model estimates smoothly the boundary layer height. The variability of the two-dimensional model results are acceptable, when compared to the radon tracer and the chamber results and also due to the integrative nature of the atmospheric methods. The uncertainties related to the fixed vegetation layer is small compared to the boundary layer estimation.

\section{Conclusions}

Hydrogen deposition velocities in urban environment were measured. The field measurements were made using the closed-chamber technique. The results calculated from the field measurements were further compared and verified with the modeled hydrogen deposition velocity values applying the two-dimensional model and the radon tracer method. The hydrogen deposition velocity values obtained from all three methods were in good agreement with each other. Based on the chamber measurements in rainy conditions the decreased deposition velocity suggests that the increased soil volumetric water content hinders the gas diffusion into ground leading to decreased hydrogen deposition velocity rate. The soil volumetric water content values did not vary enough to see clear moisture dependency among the hydrogen deposition velocity values. However a good agreement was found between the modeled and the measured hydrogen deposition values compared to one week cumulative rain.
Acknowledgements. We would like to thank Noora Eresmaa for the analysis of ceilometer results. This work was supported by the Tor and Maj Nessling Foundation, the Academy of Finland and by EU-project EUROHYDROS.

Edited by: M. Petters

\section{References}

Aalto, T., Hatakka, J., Karstens, U., Aurela, M., Thum, T., and Lohila, A.: Modeling atmospheric $\mathrm{CO}_{2}$ concentration profiles and fluxes above sloping terrain at a boreal site, Atmos. Chem. Phys., 6, 303-314, 2006, http://www.atmos-chem-phys.net/6/303/2006/.

Aalto, T., Lallo, M., Hatakka, J., and Laurila, T.: Atmospheric hydrogen variations and traffic emissions at an urban site in Finland, Atmos. Chem. Phys., 9, 7387-7396, 2009, http://www.atmos-chem-phys.net/9/7387/2009/.

Albert, M. R. and Shultz, E. F.: Snow and firn properties and airsnow transport processes at Summit, Greenland, Atmos. Environ., 36, 2789-2797, 2002.

Barnes, D. H., Wofsy, S. C., Fehlau, B. P., Gottlieb, E. W., Elkins, J. W., Dutton, G. S., and Novelli, P. C.: Hydrogen in atmosphere: Observations above a forest canopy in a polluted environment, J. Geophys. Res., 108, 4197, doi:10.1029/2001JD001199, 2003.

CFD Flow Modeling Software and Solutions from Fluent: http:// www.fluent.com/software, last access: 21 September 2009.

Conen, F. and Robertson, L. B.: Latitudinal distribution of radon222 flux from continents, Tellus B, 54, 127-133, 2002.

Conrad, R.: Soil microorganisms as controllers of atmospheric trace gases $\left(\mathrm{H}_{2}, \mathrm{CO}, \mathrm{CH}_{4}, \mathrm{OCS}, \mathrm{N}_{2} \mathrm{O}\right.$ and $\left.\mathrm{NO}\right)$, Microbiol. Rev., 60, 609-640, 1996.

Conrad, R. and Seiler, W.: Contribution of hydrogen production by biological nitrogen fixation to the global hydrogen budget, J. Geophys. Res., 85, 5493-5498, 1980.

Conrad, R. and Seiler, W.: Influence of temperature, moisture and organic carbon on the flux of $\mathrm{H}_{2}$ and $\mathrm{CO}$ between soil and atmosphere: Field studies in subtropical regions, J. Geophys. Res., 90, 5699-5709, 1985.

Constant, P., Poissant, L., and Villemur, R.: Isolation of Streptomyces sp. PCB7, the first microorganism demonstrating highaffinity uptake of tropospheric $\mathrm{H}_{2}$, The ISME Journal, 2, 10661076, 2008.

Constant, P., Poissant, L., and Villemur, R.: Tropospheric $\mathrm{H}_{2}$ budget and the response of its soil uptake under the changing environment, Sci. Total Environ., 407, 1809-1823, 2009.

Dörr, H. and Münnich, K. O.: ${ }^{222} \mathrm{Rn}$ flux and soil air concentration profiles inWest Germany, Soil ${ }^{222} \mathrm{Rn}$ as a tracer for gas transport in the unsaturated soil zone, Tellus B, 42, 20-28, 1990.

Davidson, E. A., Savage, K., Verchot, L. V., Navarro, R.: Minimizing artifacts and biases in chamber-based measurements of soil respiration, Agr. Forest Meteorol., 113, 21-37, 2002.

Ehhalt, D. H. and Rohrer, F.: The tropospheric cycle of $\mathrm{H}_{2}$ : a critical review, Tellus B, 61, 500-535, 2009.

Geological Survey of Finland: http://geomaps2.gtk.fi/geo/, last access: 23 April 2009.

Guo, R. and Conrad, R.: Extraction and characterization of soil hydrogenases oxidizing atmospheric hydrogen, Soil Biol. 
Biochem., 40, 1149-1154, doi:10.1016/j.soilbio.2007.12.007, 2008.

Hammer, S. and Levin, I.: Seasonal variation of the molecular hydrogen uptake by soils inferred from continuous atmospheric observations in Heidelberg, south-west Germany, Tellus B, 61, 556-565, 2009.

Hatakka, J., Aalto, T., Aaltonen, V., Aurela, M., Hakola, H., Komppula, M., Laurila, T., Lihavainen, H., Paatero, J., Salminen, K., and Viisanen, Y.: Overview of atmospheric research activities and results at Pallas GAW station, Boreal Environ. Res., 8, 365384, 2003.

Lallo, M., Aalto, T., Laurila, T., and Hatakka, J.: Seasonal variations in hydrogen deposition to boreal forest soil in southern Finland, Geophys. Res. Lett., 35, L04402, doi:10.1029/2007GL032357, 2008.

Lallo, M., Aalto, T., Laurila, T., and Hatakka, J.: Hydrogen soil deposition in northern boreal zone, Boreal Environ. Res., 14, 784793, 2009

Langendörfer, U., Cuntz, M., Ciais, P., Peylin, P., Bariac, T., Milyukova, I., Kolle, O., Naegler, T., and Levin, I.: Modelling of biospheric $\mathrm{CO}_{2}$ gross fluxes via oxygen isotopes in a spruce forest canopy: a ${ }^{222} \mathrm{Rn}$ calibrated box model approach, Tellus B, 54, 476-496, 2002.

Launder, B. E. and Spalding, D. B.: Lectures in mathematical models of turbulence, Academic Press, London, UK, 1972.

Levin, I., Glatzer-Mattheier, H., Marik, T., Cuntz, M., Schmidt, M., and Worthy, D. E.: Verification of German methane emission inventories and their recent changes based on atmospheric observations, J. Geophys. Res., 104, 3447-3456, 1999.

Levin, I., Born, M., Cuntz, M., Langendörfer, U., Mantsch, S., Naegler, T., Schmidt, M., Varlagin, A., Verclas, S., and Wagenbach, D.: Observations of atmospheric variability and soil exhalation rate of radon-222 at a Russian forest site, Tellus B, 54, 462-475, 2002.

Nazaroff, W. W.: Radon transport from soil to air, Rev. Geophys., 30, 137-160, 1992.

Paatero, J., Hatakka, J., and Viisanen, Y.: Concurrent measurements of airborne radon-222, lead-210 and beryllium-7 at the PallasSodankylä GAW station, Northern Finland, Air Quality Research Report 1998:1, Finnish Meteorological Institute, Helsinki, 1998.

Rahn, T., Eiler, J. M., Kitchen, N., Fessenden, J. E., and Randerson, J. T.: Concentration and D of molecular hydrogen in boreal forests: Ecosystem-scale systematic of atmospheric $\mathrm{H}_{2}$, Geophys. Res. Lett., 29, 1888, doi:10.1029/2002GL015118, 2002.

Rahn, T., Eiler, J. M., Boering, K. A., Wennberg, P. O., McCarthy, M. C., Tyler, S., Schauffler, S., Donnelly, S., and Atlas, E.: Extreme deuterium enrichment in stratospheric hydrogen and the global atmospheric budget of $\mathrm{H}_{2}$, Nature, 424, 918-921, 2003.

Rhee, T. S., Brenninkmeijer, C. A. M., and Röckmann, T.: The overwhelming role of soils in the global atmospheric hydrogen cycle, Atmos. Chem. Phys., 6, 1611-1625, 2006, http://www.atmos-chem-phys.net/6/1611/2006/.
Röckmann, T., Rhee, T. S., and Engel, A.: Heavy hydrogen in the stratosphere, Atmos. Chem. Phys., 3, 2015-2023, 2003, http://www.atmos-chem-phys.net/3/2015/2003/.

Sander, S. P., Friedl, R. R., Golden, D. M., Kurylo, M. J., Moortgart, G. K., and co-authors: Chemical kinetics and photochemical data for use in atmospheric studies, NASA/Jet Propulsion Laboratory, Pasadena, CA, Evaluation No. 15, JPL Publication 06-2, 2006.

Schery, S. D., Gaeddert, D. H., and Wilkening, M. H.: Factors affecting exhalation of radon from a gravelly sandy loam, J. Geophys. Res., 89, 7299-7309, 1984.

Schmidt, M., Glatzel-Mattheier, H., Sartorius, H., Worthy, D. E., and Levin, I.: Western European $\mathrm{N}_{2} \mathrm{O}$ emissions: a top-down approach based on atmospheric observations, J. Geophys. Res., 106, 5507-5516, 2001.

Schmitt, S., Hanselmann, A., Wollsschläger, U., Hammer, S., and Levin, I.: Investigation of parameters controlling the soil sink of atmospheric molecular hydrogen, Tellus B, 61, 416-423, doi:10.1111/j.1600-0889.2008.00402.x, 2008.

Smith-Downey, N. V., Randerson, J. T., and Eiler, J. M.: Molecular hydrogen uptake by soil in forest, desert and marsh ecosystems in California, J. Geophys. Res., 113, G03037, doi:10.1029/2008JG000701, 2008.

Simmonds, P. G., Derwent, R. G., O’Doherty, S., Ryall, D. B., Steele, L. P., Langenfelds, R. L., Salameh, P., Wang, H. J., Dimmer, C. H., and Hudson, L. E.: Continuous high-frequency observations of hydrogen at the Mace Head baseline atmospheric monitoring station over the 1994-1998 period, J. Geophys. Res., 105, 12105-12121, 2000.

Szegvary, T., Leuenberger, M. C., and Conen, F.: Predicting terrestrial ${ }^{222} \mathrm{Rn}$ flux using gamma dose rate as a proxy, Atmos. Chem. Phys., 7, 2789-2795, 2007, http://www.atmos-chem-phys.net/7/2789/2007/.

Vesala, T., Järvi, L., Launiainen, S., Sogachev, A., Rannik, U., Mammarella, I., Siivola, E., Keronen, P., Rinne, J., Riikonen, A., and Nikinmaa, E.: Surface-atmosphere interactions over complex urban terrain in Helsinki, Finland, Tellus B, 60, 188-199, doi:10.1111/j.1600-0889.2007.00312.x, 2008.

Yonemura, S., Kawashima, S., and Tsuruta, H.: Continuous measurements of $\mathrm{CO}$ and $\mathrm{H}_{2}$ deposition velocities onto an andisol: uptake control by soil moisture, Tellus B, 51, 688-700, 1999.

Yonemura, S., Kawashima, S., and Tsuruta, H.: Carbon monoxide, hydrogen, and methane uptake by soils in a temperate arable field and a forest, J. Geophys. Res., 105, 14347-14362, 2000.

Zahorovski, W., Chambers, S., Williams, A. G.: Radon-222 as a tracer of atmospheric transport phenomena on different spatial and temporal scales, in: Proceedings of 15th Pacific Basin Nuclear Conference (15PBNC), Sydney, Australia, 15 October 2006, 6 pp., 2006. 